\title{
Ensuring living condition for ageing population by public-private partnership (PPP)
}

\author{
Miha Konjar ${ }^{1, *}$, Matej Nikšič², Janez Peter Grom ${ }^{1}$, Sabina Mujkić², and Alenka Fikfak ${ }^{1}$ \\ ${ }^{1}$ University of Ljubljana, Faculty of architecture, 1000 Zoisova 12, Ljubljana, Slovenia \\ ${ }^{2}$ Urban Planning Institute of the Republic of Slovenia, 1000 Trnovski pristan 2, Ljubljana, Slovenia
}

\begin{abstract}
Lack of financial resources has become one of the main issues in fulfilling social and physical needs in urban development. The declining levels of public resources make the collaboration between public and private investors necessary. When facing the challenges of ageing population, shared investment may contribute to the appropriate development of sheltered housing to meet the goals of spatial planning as well as certain standards at the level of urban design. By ensuring appropriate living conditions for all generations such urban PPP projects may contribute to the fulfilment of the public interest. The paper presents practice of PPP implementation in Ljubljana, Slovenia, where local authority with the collaboration of private partners ensured more than 400 sheltered apartments in the last years. Examples show the extension of the idea from the $70 \mathrm{~s}$ onwards in finding new models of housing for the aging population. The development of new models can be a good example of strengthening the cooperation between public and private partners in the field of urban development practice.
\end{abstract}

\section{Introduction}

Today's apparently "chaotic" settlement pattern in Slovenian suburbia and countryside is a consequence of political, social and economic conditions and changes that have been taking place in the post-WWII period for the last fifty years. The ideological orientation of the communist movement gave absolute priority to collective society and interests. A higher level of collectivism was to be achieved more by restriction rather than considering individual interests. In physical planning social housing construction was favoured. Uniform models and standards were predominant both for large urban agglomerations as well as for rural areas. Restrictions and directed construction together with regulated planning were supposed to give a complete overview of everything that was taking place in space [1]. Decline of policies on detached housing was one of the reasons why organized and planned forms of housing cooperatives were not developed. At the same time the priority given to social housing served as an efficient instrument to achieve quality and certain aesthetic level of organized settlement pattern.

The need for a new type of dwellings has occurred and was left to new processes of prestructuration in agrarian economy accompanied with the social and demographic

${ }^{*}$ Corresponding author: miha.konjar@fa.uni-lj.si 
restructuring (abandonment of agrarian land and employment in industry) [2]. The first turning point in the development of legislation were the laws adopted in 1967 about urban planning [3] and a regional spatial planning law [4]. This legislation was first used for urban planning at the level of municipalities. It was meant as a guideline for development in urban areas, while avoiding spatial dispersion of single-family houses in extra-urban area (including urban periphery). The changes in the production system of rural space based on mixing and complementing of agrarian with non-agrarian functions, influenced the change of traditional settlement patterns and of their constituent parts - "homes" - by introducing new typologies. The countryside was left to develop by itself. Facilities were built individually, mostly in the form of replacement construction for the old farms. The design and construction were still based on the typology of social housing as a "free-standing singlefamily residential house, positioned in the middle of the plot". This process exploded in the 1970 's and drastically changed the settlement patterns in Slovenian.

The conducted research deals with the given topic comprehensively and interdisciplinary, with the integration of practical knowledge from different fields, such as: Urbanism, Architecture, Landscape Architecture, Spatial planning, Administration, Law and Economy. The aim of this research was to identify the connection between problems of housing for ageing population and the development of models for implementation in a PPP manner. Special attention was given to the realization of the public interest in such projects, especially from the point of view of urban design and spatial planning goals to ensure quality living environments. Comparable projects, national as well as international, have been taken into consideration while trying to determine the current level of PPPs in Slovenia. The working method has been oriented towards a review of sites developed by PPP and their urban dimensions. The research was focused on 11 Slovenian city-municipalities where semi structured interviews in the form of informal discussions were conducted. The paper presents a case study of shelter housing development as PPP in Ljubljana, Slovenia.

When exploring contemporary housing issues in relation to the issue of the aging population in Slovenia and also elsewhere some important questions have to be raised.

- How to grant the older generation decent living conditions?

- What is happening with the housing fund built during the 70's in which elderly live today?

- Do these buildings offer suitable conditions for the elderly?

- How does the housing policy reflect different aspects of public interest?

- How do public-private partnerships (PPPs) address the development of housing?

- Do sheltered apartments respond to the context of a socially useful "public interest" and allow and support a long-term investment for and to the society and its social environment?

\section{Ageing in Slovenia}

The aging of the population is a general process in Slovenia and elsewhere in developed word that cannot be avoided. When we are talking about life of elderly today, we are no longer talking about a few years after retirement, but about a life period of 20-30 years. The elderly maintain their independent life longer and longer, independent of care and help. Of course, their needs increase over the years, but in general the old population of today is "rejuvenated", people remain active and vital after retirement for a long time [5]. As a result, the old population is becoming more and more heterogeneous, and therefore the boundary between middle age and old age cannot be precisely defined. The paradox of today's society of the third life period is that older people have more personal freedom but fewer possibilities for achieving their goals [6].

The share of the population aged 65 increased from $10.6 \%$ to $16.5 \%$ in the period from 1989 to 2009 . In the same period, the share of the population aged $0-14$ decreased from $20.9 \%$ to $14.0 \%$ [7]. Such a trend is projected to continue; in 2029, at least 65 years old residents 
would be $24.8 \%$, and in $205933.5 \%$ [8]. Only $12.8 \%$ are supposed to be 15 years old at that time. The population of Slovenia will not only be much lower but it will also be significantly older according to these assumptions. According to the forecasts, the number of those aged 65 or more will represent one third (33.4\%) of the entire population by the end of 2060 [7]. Another matter are the living conditions of the elderly and their spatial exclusion. Studies show that in Slovenia around $20.8 \%$ of the elderly live in unfit conditions (with at least one issue - overcrowding, humidity, lack of space, no bathroom or toilet), while the spatial exclusion is even much higher. The problem of spatially excluded older people, that do not have basic services in their vicinity, is extremely problematic as they represent $49.2 \%$ in this demographic group [9].

Demographic studies predict large changes in the structure of the population in the next decades, due to the already mentioned negative demographic trends. As we are still not able to comprehend such a social phenomenon, we are still not able to cope with it neither in a cultural or political sense. As a result, if these unpredicted consequences are not entirely dealt with, the old age will make the ageing population progressively more excluded and isolated without guaranteed medical care.

\section{Housing in Slovenia: social environment and financial mechanisms}

Marta and France Ivanšek, pioneers in research of Slovenian housing, work had extreme importance and impact for Slovenian post-war architecture, urban design and planning, and society in general. Several key movements were promoted by their actions, which were advanced and unique for Slovenian space. They dealt with housing systematically and comprehensively. The major influence on their vision, attitude and reflections had a five-year work period spent in Sweden. The efforts of the Swedes for a Highly-Living Culture made a great impression on them. Economical attitude to space, retained design and social ideas typical of Scandinavia have become the main motive of their work. On the basis of these experiences and their own vision they established the Department for Housing Research at the Urban Planning Institute where they carried out the first residential research for a higher standard of living. Their work in this field is regarded as pioneering, since they were the first in Slovenia, that systematically monitored the state and development of housing construction, investigated the quality and utility value of apartments and living habits as well as the desires of people. On the basis of the results of this research, they established further orientations of their work, both planning and awareness-raising by educating users about their own living environment. Their work and efforts were based on three main approaches: research of urban and architectural arrangements of settlements (housing research), interior design, and education of people, that was intended to raise the awareness of people in the field of housing. The goal of their work was to improve the living environment of all people in everyday life, to create beautiful and comfortable homes for everyone and to raise the living culture of the Slovenian population. Special dedication was given to understand the one-family house, the free-standing house which gives the designer and the tenant relative maximum individual freedom. However, when such freedom leads to the fact that from someone's kitchen the only possible view is to the neighbour's bedroom, the view from the cooking corner to the neighbour's living room and with the terrace that does not allow any privacy, all the relative advantages of this individual freedom quickly disappear and such situation can quickly turn into an absolute failure [10].

The Ivanšek were convinced that a quality residential space is one of the basic needs of every human being, particularly the elderly. The transition to creating a better living environment for the elderly was therefore an understandable step in their careers. Initial research in this field produced the results at an early stage. They created special interior 
design elements and furniture (Retirement Centre Tabor, Ljubljana, 1965) which lead them to the design of designated housing for older people (Pensioners' House in Poljan, 1973-75 and Kolezija, 1979-82 in Ljubljana). Still today Marta and France Ivanšek's principles can be applied when solving contemporary housing problems to ensure the appropriate quality of living.

Slovenian planning legislation states that the main objective of spatial planning is to enable coherent spatial development by the consideration and coordination of different development needs and interests and assuring public benefits, especially in the areas of environmental protection, the conservation of nature and cultural heritage, etc. As it can be seen, from one of the basic principles of spatial planning, the identification and consideration of the public interest is one of the key components of spatial planning in general. One of the main principles in spatial planning is the dominance of the public interest, which requires state and municipal authorities to take into account both public and private interests, carefully consider them both in accordance with the objectives of spatial planning and ensure that private interests do not negatively affect the public one [11]. Gantar [12] points out that local or state institution do not have the legitimacy for interventions in space, which can by their nature restrict certain civil rights, if such an intervention is not justified by the public interest. More than that, this public interest must be legally codified through specific forms of legal acts (spatial plans of various forms) [13]. Alexander [14] lists three roles of public interest in connection with spatial planning:

- the legitimization of the state's functioning, which is related to the planning,

- sets a norm for planning practice, and

- serves as a criterion for the evaluation of planning and its products (plans, projects and policies).

Planners encounter conflicting interests of individual actors (users of space, local communities, investors, representatives of other professions, etc.). When this happen, the spatial planner should act as a neutral negotiator among the participant stakeholders [15]. Gantar [12], however, draws attention to the possibility of a discrepancy between the planner's professional conviction and the public interest. He highlights the existence of a dilemma: "Should the planner simply accept the definition of a public interest in relation to a certain intervention in a space as it is, or whether it should be actively involved in its design and therefore a certain degree of politicization of his operation" [12].

Between different public interests the quality of life of all generations is equally important, as it is the life span. Therefore, the aging population should be equally enabled to live the same full, active, healthy, safe and satisfied life as integral part of the society. In the foreground comes the phrase "active age", which emphasizes that this is not a passive period of life, but the period in when people should come to life with new forms of socially beneficial activity.

\subsection{Overview of housing financing in 20th century in Slovenia}

One of the essential factors for planned construction is also the economic scheme or the provision of financial resources, which is conditioned by the relevant legislation [16]. This area has changed together with the socio-political system in Slovenia. We can define eight major time-bound sets that have been conditioned by different types of financing from the beginning of the 20th century to this day:

1) [Before the Second World War] - Controlled development of housing can be found only in cities. In addition to privately built and owned houses, there was also a fund of profitable apartments, owned by large and small private investors, intended for renting. Municipalities and private legal entities owned a certain proportion of social non-profit apartments intended for socially endangered population. Additionally, a special type of rental 
housing intended for employed and residential "colonies" existed too, owned by large companies, usually located in a vicinity of operating industrial facilities.

2) [1945-1956 Restoration years] - With large scale industrialisation programmes the influx of new residents into the urbanised centres became increasingly strong. The National Committees established offices that had oversight over the entire housing stock at the local level. During this period, housing was an essential instrument of social policy - minimum living conditions were guaranteed to every citizen. There were some changes introduced between 1947 and 1956. On one hand, the housing right and the resulting rights to the unhindered use of the dwelling and the prohibition of silence and displacement of the inhabitants were permanently entrenched; and on the other hand the financing of housing construction was settled through the state budget. Collective housing and the first neighbourhoods were built with budgetary funds. The socially-owned housing was mainly intended for political and professional staff. The social function of housing policy has declined; instead, housing policy has become part of human resources policy.

3) [1956-1965] - In 1956, municipal housing construction funds were formed from the compulsory contribution; from the income of employees. This created a relatively broad economic basis for more extensive construction. Individuals were able to get a loan from municipal funds for the construction of single-family houses. Newly established funds were the basis for the development of housing construction and related industry. The law on the nationalization of apartments for rent and construction land entered into force in 1958, bringing new developments in the field of housing policy: 1) The law enforced a class attitude towards renting buildings and building land; and 2) It was estimated that official underdeveloped construction operative bodies would not be able to cope with the existing funds intended for housing construction. The principle of land acquisition through expropriation was too slow and nationalization took place. Agricultural land was mainly nationalized in the vicinity of cities, which caused their rapid spread. During this period, the growth of individual buildings, mainly one family houses has caused the extensive urban sprawl.

4) [1965-1972] - An economic reform came into act in 1965. With the resolution on the further development of the housing economy system, the whole mechanism of the housing economy moved into the economic field. The society has supported the development of construction companies in housing and residential expansion. This way the housing policy was deprived of the social component. Deformations occurred in the housing construction model: 1) The price-structure was not public and the producers behaved in a monopoly way, consequently the prices rose; and 2) There were no norms on the size and structure of the dwellings (the price of $\mathrm{m} 2$ of housing was the same for one- or two-room dwelling). Since housing policy had no longer a social component, many of the working people could not solve housing basic situation. These reasons led to the construction of solidarity apartments, which were financed only by current buyers and construction companies, and not by the society as a whole.

5) [1972-1990] - Housing projects were financed by companies and others so called users of social assets. Funds were collected in several ways: 1) Income from solidarity (nonrefundable) pooling - for solidarity housing construction; 2) Funds from net income for reciprocal pooling - for solving housing issues for company employees, for the construction and renovation of private homes, single-family homes, etc.; and 3) Funds from net income, disbursed after the final account - for solving the housing problems of employees, providing loans to employees, for earmarking in banks, etc. Until 1987, the volume of housing construction was relatively high, and in the early 1980s, more than 10,000 dwellings were built each year. In the second half of the 1980 s, the share of housing construction in the social sector began to decline compared to the private sector. In 1989, real interest rates were 
introduced. With the elimination of self-management socialism, the then existing housing system was abolished.

6) [1991-1999] - The Housing Act [17] brought two essential novelties in the housing field: 1) Social ownership in the residential sector was abolished. The main driving force was a process of privatization, which was based on a concept of purchase under the very advantageous conditions, which led to the divestment of social housing. 2) The Housing Fund of the Republic of Slovenia (1991) was established, which was supposed to finance the national housing program, encourage housing construction, renovation and maintenance of apartments and houses. The Housing Act is based on the principle that the concern for resolving the housing problem lies on every individual, with social corrections when the state provides for those who cannot solve it alone. Instead of the principle of "providing housing" that was used in the past, the term "facilitating the acquisition of housing" is introduced. In this way, the housing area was de-bureaucratized, and the administrative allocation of housing was replaced by the procedures of the organized housing market and by supporting private initiatives. The most important provider of housing loans with a favourable interest rate is the Housing Fund of the Republic of Slovenia. The main source of financing for the fund was a $20 \%$ share of the purchase price during the privatization of housing. Under the provisions of the Housing Act, housing funds may also be established by municipalities and non-profit housing organizations. However, funds are lacking in particular for lending to social and non-profit housing. The law categorized types of housing: owned, non-profit, social, office and profit housing.

7) [1999-the present time] - The national housing savings scheme, adopted by the government in 1999, increased the volume of favourable housing loans, as it encourages long-term savings. The national savings scheme is implemented through the Housing Fund of the Republic of Slovenia and the banks that are selected by the public tender. The attractiveness of such savings is provided in the form of attribution of a certain amount of the premium after the expiry of each saving year. At the same time, savers are offered comfortable housing loans. Long-term savings in the country are expected to provide a sufficient amount of funds in the future for favourable long-term housing loans. In 1998, the Housing Fund issued the second, in 2001 the thirds, in 2002 the fourth bonds issue for legal entities, intended for recapitalization of the Fund for the implementation of its legally defined activities. The construction and renovation should provide at least 10,000 apartments annually in Slovenia. According to the National Housing Program, about 2,500 non-profit rental apartments, 2,000 social rental apartments, 5,000 own homes and 500 profitable apartments.

8) [present time] - The period of Public-private partnerships (PPP), which play an important role as an instrument of planning and implementation of public infrastructural projects, including urban projects that affect the dynamics of urban development. Even if in Slovenia PPP sector is still partly underdeveloped (the Public-Private Partnership Act [18] was for example adopted only in 2007), the PPP principle shows high potential for achieving spatial planning and urban development goals. When used correctly the PPP tool could enable the successful realization of different urban projects, which would be otherwise often hindered or even not realized due to the financial obstacles.

\section{Public-private partnership (PPP)}

Well defined PPPs are often mentioned in the context of privatization, but it is necessary to distinguish between the two concepts. Unlike privatization, PPPs operate on the basis of a joint decision-making process where public and private partner's interests have been interpreted and defined in a contract or some other form of agreement [19]. In the Green Paper [20], the European Commission defines partnerships as: "cooperation between public 
authority and the business world, which is intended to provide financing, construction, reconstruction, management, maintenance of infrastructure or the provision of services".

PPPs, on the principle of "people in the first place«, ensure that people are key stakeholders. They focus on improving the quality of life in communities, especially in poor environments, and create local sustainable jobs that address food and health issues, strive for gender equality, regulate access to drinking water, energy, transport and education for all, encourage social cohesion and fair regulation, and try to eliminate all kinds of racial, ethnic, religious and cultural discrimination. Public-private partnerships are being promoted and expanded, as they give people access to better services at more favourable prices.

The good governance of the public sector is the public interest. The public sector thus works in the public interest, and the limits of orientation towards the user are determined by the public interest, which means that the public interest also directs the amount and method of public activity in a particular field. The public concern is more complex, driven by legislation, regulation and authorities, political opinion, democratic decision making, minimizing the risk and maximizing the social value [21]. PPPs are generally developed for public interest missions: roads, railways, ports, airports, water and wastewater, waste, energy, health, security and prisons, to give some examples. The government, the ultimate guardian for the provision of these services, entrusts the private sector with the responsibility of designing, financing, building and operating the infrastructure and/or service [22].

\subsection{PPP tool in Slovenian spatial development}

The PPP tool has been introduced into Slovenian spatial development practice rather recently. Most often different improvement of the quality of the living environment are achieved by the implementation of PPP, which also contributes to a more controlled creation of urban space and increases the flexibility of the traditionally rather ossified planning process in Slovenia. The lack of regional administrative level and due to a division of Slovenia to 212 small municipalities at a local level, Slovenia has a specific pattern when implementing PPP practice. In general, there are few PPP projects that exceed the threshold value to apply for some EU founds available for example in the new EU Investment Plan.

The Slovenian legislation defines the PPP as $» . .$. the ratio of private investment to public projects and / or public co-financing of private projects in the public interest and cooperation between public and private partners in connection with the construction, maintenance and management of public infrastructure or other projects of public interest ...« [18]. Such a public-private partnership necessarily includes at least the provision of services representing a public service or service otherwise carried out in the public interest, the construction of facilities and facilities necessary for the provision of such services (public infrastructure) or, as a general rule, both the construction of public infrastructure and the provision of public services. The essential element of public-private partnership is the public interest, and this element should not be neglected by the State and the local community, but they must undoubtedly address it in this relationship.

\subsection{The role of the "public interest" in PPP in Slovenia}

The role of "public interest" is crucial in the implementation of PPP. In the draft of the new Act on Investment Incentives [23], the public interest is defined as follows: "The public interest is the general interest of the organized wider community or the welfare of the general public, according to its value criteria of its benefit, from the increase in capital, the capacity to increase production capabilities and technological progress towards the direct and indirect creation of new jobs, with the transfer of knowledge and technologies, and cooperation with educational institutions that are above the interest or the benefit of the individual. The 
implementation of a strategic investment is what is considered to be in the public benefit, which, due to spatial, technological and logistical needs, is suitable for insertion in space and fosters economic development."

The National Housing Program [24] envisages the next strategy in relation to the public interest, PPP and building development. The program specifies housing cooperatives as an additional source of funding for housing construction: "An additional source of funding for housing construction will also be housing cooperatives, which are a form of housing selfhelp for citizens in partnership with the public-sector" [24]. Housing cooperatives have a form of housing self-help for citizens in partnership with the public sector. As these will be public works, housing cooperatives will receive various benefits from the public sector, in particular favourable loans or subsidies for interest and guarantees for loans and land at favourable prices, for sale or long-term lease. The value of the dwelling will be determined by the actual costs of the construction of the dwelling or housing. To ensure and enforce that the system will work in favour of the tenants the investor will have to provide low building expenses. This will have to be achieved without compromising on the safety and other building standards, but rather be achieved by building on cheaper land and with thoughtful, modest building details and finalization. The investor will find cheaper land in cooperation with the municipality by public-private partnership.

\section{Housing, sustainable urban strategies and the use of PPPs in the city of Ljubljana}

Ljubljana offers a vast distinction of different types of housing which were recognized as one of the cultural values of the city (Fig. 1).

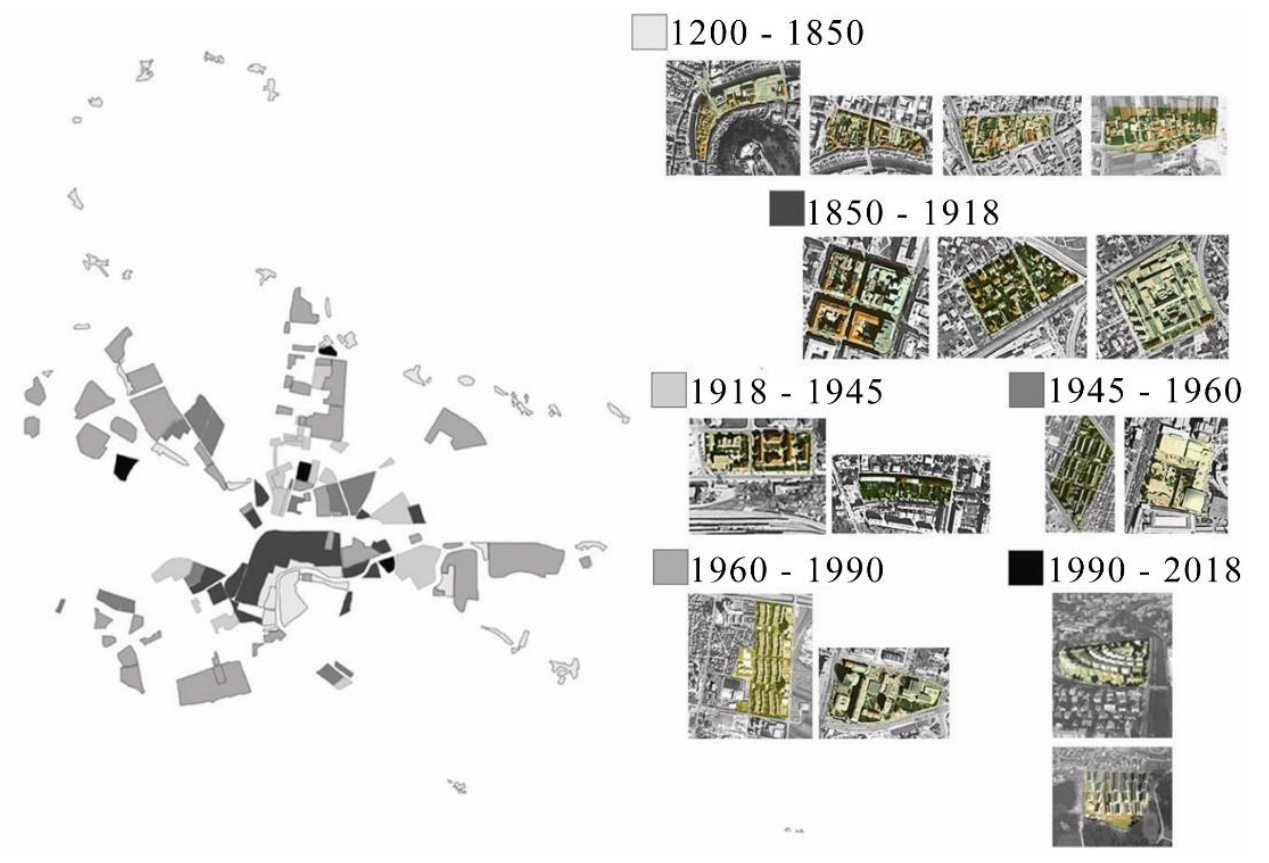

Fig. 1. Characteristic areas in Ljubljana [25].

The general contents of the recently adopted Sustainable Urban Strategies (SUS) for the city municipality of Ljubljana (MOL) that entitles different goals and directions for future urban development of the city are: 
- Sustainable (co-natural) development addressing more sustainable form and functioning of cities and their influential areas.

- Economic development with the goal to ensure good conditions for preservation and creation of new jobs and opening of new business opportunities.

- Rise of living conditions by providing a high quality living environment and ensuring high environmental standards, quality green and open public spaces, quality renovation of residential and other parts of the city, preservation of cultural heritage, etc.

- Development of urban character connected to the development of (new) urban functions, social infrastructure, public spaces of urban character, revitalization of degraded areas and cultural heritage with city functions, development of cultural activities, revitalization of neighbourhoods in areas of good urban life standard etc.

- New forms of management such us new forms of decision-making and city management.

The directions mentioned in the SUS MOL [26] are important also from the perspective of the implementation of PPP projects. Additionally, SUS defines the mayor suitable locations for urban project placement. Identified degraded areas are some of these locations. The current success of PPP projects in Ljubljana can be also attributed to the comprehensive survey and study of degraded areas available and suitable for different urban projects [2729]. To reuse such degraded areas is also one of the strategic and at the same time main objectives of managing the territory of Ljubljana according to the strategic spatial development of Ljubljana [30] and the implementation of Municipal Spatial Plan of MOL [31]. As Burgar [29] points out, the deteriorated areas of a city are valuable urban development areas, where the City of Ljubljana should challenge itself and enforce public interest in order to reinvent beyond the speculative logic of the market. Two examples of renovation of brownfields, which were carried out as PPP projects are the construction of a multi-purpose football stadium, a sports hall and an accompanying building with the service infrastructure in the Stožice district, and the Center for Contemporary Arts "Rog".

The overview of newsletters published in the Official Gazette of the Republic of Slovenia [32] reveals a multitude of acts on the topic of the implementation of PPP projects adopted in MOL: Ilirija - implementation of the construction of the Ilirija Swimming and Gymnastics Center; Introduction of a wireless network in the area of the City of Ljubljana; Underground car-park under Plečnik's market and the extension of the "Mahrova" house; renovation of Vodnik's square and the underground car-park under the "Krekov" square with its renovation; Sports Park "Črnuče"; Revitalization of the sports center "Savsko naselje"; National Gymnastics Center; Sheltered apartments "Šiška”; Old Airport Ljubljana; Football Hall in "Štepanjsko" district; energy renovation of municipality owned buildings, etc.

\section{Sheltered housing projects in the City of Ljubljana, as a model of PPP}

The projects in the field of housing and housing construction is less present. The exception are the interventions in the urban space in the form of sheltered apartments carried out with the private partner Mijaks in Rožna dolina, Koseze, Murgle and Dravlje-Šiška districts. Local authorities were able, with the collaboration of private partner, to ensure more than 400 sheltered apartments in the last years.

\subsection{Sheltered apartments}

The sheltered apartments are intended for older people who are still able to live independently and are not interested in being accommodated in nursing homes. The service is carried out in the functionally connected environment with the dwellings that are adapted to the needs of 
elderly. They differ from the usual dwellings in that they are adapted for the ageing people: the buildings must stand in a well-regulated and peaceful environment, the transport infrastructure must be properly regulated and accessible, access to facilities must be good, the interior spaces of the building must be designed for the motorically less capable people in mind, medical and social care must be provided 24 hours a day (technical aids, home care, home help, organized nutrition, personal hygiene and care, protection and organization of personal contacts, transport, accommodation of emergency call devices, security of housing). An important attribute of sheltered apartments is to maintain all the advantages of conventional living standard, especially by assuring autonomy and privacy, while at the same time provide residents with all institutional care services.

Residents of sheltered dwellings generally have the option of choosing individual services or service packages depending on the amount of assistance that an individual needs, according to their state of health. Despite the fact that the basic concept of sheltered housing has already been exceeded in more developed countries, as is this next step in the development of more modern forms of living for the elderly, sheltered housing in Slovenia still does not have the effects desired. Because of the high proportion of private owned dwellings by the elderly and the lack of understanding what sheltered apartments really are and what they offer, elderly in Slovenia are still quite reserved when deciding about leaving their privately owned homes and move to such "institution". So far, there are relatively few sheltered apartments buildings in the country, but the construction trend is increasing, due to the aging of population and related necessity of care services. It is expected that this concept as a form of living for the elderly will largely replace the traditional homes for the elderly that offer(ed) only institutionalized stays.

\subsection{Case study of sheltered housing in Šiška Dravlje, Ljubljana}

The presented case study of the urban project carried out by means of a PPP, consists of the establishment and construction of two buildings intended to provide sheltered housing for elderly. It includes all the services needed in relation to the management and maintenance of the sheltered apartments throughout the whole duration of the partnership. The private partner had two years to prepare the project documentation, obtain a building permit, build the building and transfer the dwellings agreed upon to the public partner. This is an example of one of the projects carried out by the Mijaks company in partnership with the public partner Public Housing Fund of the city municipality of Ljubljana [33]. The project is called "Sheltered housing Mijaks - Ljubljana Šiška Dravlje. 54 residential units were built in 2016 with a total gross area of $4,477.76 \mathrm{~m} 2$. The success of the project is also that all the apartments were already sold in the same year as they were built. Beside the construction of sheltered apartments, the contract also predicted a provision of 46 outdoor parking spaces and the design of the surrounding area, as well as the provision of maintenance and management for the entire project. The adopted PPP model was DBFTO (design-build-finance-transferoperate) for the part transferred to the public partner while it was a DBFO (design-buildfinance-operate) for the part kept in private ownership. The criteria for selecting a private partner were focused on: finding the largest total floor space of sheltered housing offered to the public partner, finding the highest share of rented apartments for the public partner within the private part of the project, the offered market rent amount of sheltered apartments in the private part of the project and the selling price of the supplied apartments in the private part of the project.

\subsection{The method of activating publicly owned land with private capital}


For the purpose of the implementation of the project, the public partner transferred the building right to the private partner, for the construction period of the project. The scope and duration of the given building right has been agreed upon in the process of selecting a private partner. The owner of the land was the Municipality of Ljubljana. The Municipality invested in the project an area of 4,045 $\mathrm{m} 2$ intended exclusively for the construction of sheltered apartments and additional financial founds for the acquisition of the building right and other municipal contributions. The total stake of the public partner amounts to $€ 1,153,900$ (excl. VAT). For the future needs of the residents from the new sheltered apartments, the public partner also enabled the joint use of the nearby park, that is part of the already existing nursing home Šiška. Within the project, the public partner had to establish mechanisms, to ensure effective public interest protection through the whole period of the public-private partnership.

\subsection{Gains in city urban development}

The private investor found a "niche market" and successfully established cooperation with the public sector in order to improve the conditions and quality of life for the older generation in Ljubljana. In the case of sheltered housing projects, the main gain for the city municipality was to obtain a working concept of sheltered apartments, adapted for people in their third life period, providing them with a new, higher level of living quality. This reduces the pressure on nursing homes for the elderly and ensures a wider range of activities and living possibilities for the aging population. Sheltered housing is one of the important aspects of improving the quality of life which can be achieved through the combination of public sector and private funds and inputs. The construction of sheltered apartments in Ljubljana, implemented through the PPP mechanism, is a good example of a dynamic, controlled development of the city.

However, in the process that lead to the presented project there were also some mistakes made. Only by addressing these mistakes the new generation of such projects can improve. For example, the process of preparation and implementation of the project did not take into account some of the main principles of modern and sustainable spatial development such as: public participation, integration with local residents, verification of the project within the context of the existing urban plan. The definition of different urban parameters, that were supposed to regulate the project, was not done according to the existing urban design of that area, but was determined only based on the criteria and general provisions that apply according to the planned land use in the regulatory plans which are too general. One of such general provisions is also the guideline from the Sustainable urban strategy that envisage the concentration of urbanisation. This is often carried out by constructing on quality vacant plots within the urban structure, resulting in the increased build-up factors, higher population density, increased traffic which results in rising of air pollution and noise pollution. If the norms and regulations are not strictly defined, there is a high possibility that such project might bring disapproval and dissatisfaction among the public, together with some other negative effects on urban space. With the combination of over rationalization in the public sector, with the goal to achieve the planned results as soon as possible and the private sector, which is mainly driven by the possible profit, the care for the quality of life of all citizens it easily neglected. It can often happen that such combinations might affect the successful realization of the PPP project. Even more, the realization of such urban project might consequently effect or even deny the basic role and mandate of PPP that should seek for higher "public good".

\section{Conclusions}


The awareness of the importance of the existence of social housing is relatively high in the sphere of spatial development in Slovenia, where these issues are mainly addressed within the urban environments. This includes granting housing to young families, homes for the elderly, student dormitories, etc. Nevertheless, there are not many social housing projects carried out due to the lack of the legislative and financial incentives.

These types of projects may be better implemented through mutual rewards offered in the PPP processes, although they are often lacking verification from the point of view of spatial planning. These projects mostly strive for the maximization of the gross built surfaces to find positive results for both public and private partner to justify the project, but by doing so they ignore contemporary principles of urban planning and urban design, including sustainability and resilience principles. Usually synonyms of these contemporary principles, e.g. participatory urban planning and the verification of expert opinions to enforce public interest, are left out of the negotiation and planning processes. This comes partly due to the fact that the urban planners themselves lack the expertise in the field of PPP. In order to make a better use of PPP in providing more and better social housing in Slovenia some additional endeavours must be made in terms of educating public administration and decision makers on how to manage the PPP processes. On the other hand, the awareness raising is needed at the side of private investors too so that they would understand the need for a well thought and designed urban spaces which will provide a high quality urban environments and will thus enhance their funds initially invested in a long term too.

\section{Acknowledgments}

The research presented is part of the ongoing project called Analysis of options for implementing of urban projects using public-private partnership conducted by three partner institutions: two form University of Ljubljana, Faculty of Law and Faculty of Architecture and the Urban Planning Institute of the Republic of Slovenia. The project is financed by Slovenian Research Agency and Ministry of Spatial Planning of Slovenia.

\section{References}

1. S. Kosanović, A. Fikfak, Energy Building, 115, 69-77 (2016)

2. A. Fikfak, Naselbinska kultura slovenskega podeželja - Goriška brda (University of Ljubljana, Faculty of architecture, Ljubljana, 2008)

3. Zakon o urbanističnem planiranju (ZUP). Official Gazette of the RS, no. 16/67 (1967)

4. Zakon o regionalnem prostorskem planiranju (ZRPP). Official Gazette of the RS, no. 16/67 (1967)

5. R. Sendi, B. Černič Mali, A. Jakoš, M. Filipovič Hrast, Stanovanjske potrebe upokojencev in drugih starejših oseb (Urban planning Institute of the RS, Ljubljana, 2003)

6. A. Krajnc, AS, 3/99, 5-18 (1999)

7. Eurostatove projekcije prebivalstva za Slovenijo, 2008-2060, EUROPOP2008, konvergenčni scenarij (SORS, Ljubljana, 2008)

8. N. Vertot, Starejše prebivalstvo v Sloveniji (SORS, Ljubljana, 2010)

9. V. Hlebec, M. Kavčič, G. Ogulin Počrvina, Staranje, izziv za izobraževanje in medgeneracijsko sodelovanje (Zveza ljudskih univerz Slovenije, Ljubljana, 2013)

10. F. Ivanšek, Enodružinska hiša: od prosto stoječe hiše $k$ nizki zgoščeni zazidavi (Ambijent, Ljubljana, 1988) 
11. Zakon o prostorskem načrtovanju (ZPNačrt), Official Gazette of the RS, no. 33/07 (2007)

12. P. Gantar, Geodetski vestnik, 51 (2), 246-254 (2007)

13. T. Križman, Vloga civilne iniciative v slovenskem prostorskem načrtovanju, diplomska naloga (University of Ljubljana, Biotechnical Faculty, Ljubljana, 2012)

14. E. R. Alexander, Planning Theory, 1 (3), 226-249 (2002)

15. P. Bradwell, I. Johar, C. Maguire, P. Miner, Future planners, propositions for the next age of planning (Demos publications, London, 2007)

16. V. Pust, AB, 68/69, 23-24 (1984)

17. Stanovanjski zakon (SZ), Official Gazette of the RS, no. 18/91 (1991)

18. Zakon o javno-zasebnem partnerstvu (ZJZP), Official Gazette of the RS, no. 127/06 (2006)

19. L. B. Sagalyn, Journal of the American Planning Association, 73 (1), 7-22 (2007)

20. Green paper on public-private partnerships and Community law on public contracts and concessions (Commission of the European Communities, Brussels, 2008)

21. B. D. Jones, Reconceiving decision-making in democratic politics: attention, choice, and public policy (The University of Chicago Press, London, 1994)

22. C. O. Cruz, R. C. Marquez, Infrastructure Public-Private Partnerships. Decision, Management and Development (Springer-Verlag Berlin Heidelberg, 2013)

23. Osnutek zakona o spodbujanju investicij (ZSI) (Ministry of Economic Development and Technology of the RS, Ljubljana, 2017)

24. Nacionalni stanovanjski program 2013-2022 (NSP) (Ministry of the Environment and Spatial Planning of the RS, Ljubljana, 2013)

25. M. Šašek-Divjak, K. Dimitrovska Andrews, et al., Občinski prostorski načrt MOL: strateški del. Mapa 1, Odlok o Strateškem načrtu Mestne občine Ljubljana (Urban planning Institute of the RS, Ljubljana, 2009)

26. Trajnostna urbana strategija Mestne občine Ljubljana 2014-2020 (SUS MOL) (Municipality of Ljubljana, Ljubljana, 2015)

27. J. Koželj, L. Ažman Momirski, T. Maligoj, B. Omerzu, D. Flere, Degradirana urbana območja (Ministry of Environment and Spatial Planning of the RS, Ljubljana, 1998)

28. J. Koželj, P. Filipič, P. Hočevar, K. Strle, D. Kušar, Merila in kriteriji za določitev degradiranih urbanih območij (DUO) (University of Ljubljana, Ljubljana, 2016)

29. B. Burgar, Vključevanje mesta v prenovo degradiranih območij in ponovno uporabo obstoječih objektov (Municipality of Ljubljana, Ljubljana, 2003)

30. M. Šašek Divjak, Urbani izziv, 19 (1), 11-24 (2008)

31. Municipal Spatial Plan of the City Municipality of Ljubljana, Official Gazette of the RS, no. 87/2010 (2010)

32. Official Slovenian Newsletter, https://www.uradni-list.si/glasilo-uradni-list-rs/vsebina/ (accessed on 17 March 2017)

33. Project presentation. Sheltered housing Mijaks Šǐ̌ka Dravlje (Mijaks, Ljubljana, 2017) http://mijaks.si/slovensko/oskrbovana-stanovanja-mijaks/dravlje-siska/ (accessed on 16 March 2017) 